\title{
39th ARA Congress Lucian Grigorescu
}

\author{
Dr. Carmen Sabau CSabau@comcast.net, \\ Dr. Isabelle Sabau cyberedu22@netscape.net
}

\begin{abstract}
This presentation continues the series dedicated to the Modern Romanian Art Masters of the late $19^{\text {th }}$ and $20^{\text {th }}$ centuries and their important contribution to the evolution of Romanian Art. This paper examines the work of Lucian Grigorescu (1894-1965), an important and original Romanian Post-Impressionist, who skillfully fused the perceptual vision of the impressionists with the structural analysis of the post-impressionists and unique Romanian motifs. Lucian Grigorescu created a balance between tradition and modernity infused with a personal sensibility and delight in nature rendered through a vigorous construction of form bathed in color and light. This paper proposes to unveil the unified continuity of a spiritual and material universe rendered through a vivacious symphony of color and the virtuosity of brush strokes in the oeuvre of the great colorist Lucian Grigorescu through an analysis of some of his important works.Introduction.
\end{abstract}

\section{Introduction}

The evolution of Modern Romanian Art includes significant influences from the various styles that arose throughout Europe during the late $19^{\text {th }}$ and $20^{\text {th }}$ centuries, but is infused with strong indigenous characteristics based on the unique Romanian landscape and way of life. Among the great Romanian artists of the early $20^{\text {th }}$ century Lucian Grigorescu stands out as one of the most important colourists whose paintings exhibit a chromatic vivacity of colour revealing the subtle variations of the landscape motifs, especially those of Cassis and Dobrogea that permeate his oeuvre. Lucian Grigorescu is considered a postimpressionist but his importance lies in his contribution to the art of the $20^{\text {th }}$ century through the unique combination he achieved especially in landscape painting through which, following the example and influence of Andre Derain and Paul Cezanne, he opened new horizons in the expression of nature filtered by his own unique sensibilities. Although Lucian Grigorescu's oeuvre primarily focuses on landscape, human nature and portraiture also interested him, which he rendered with great sensitivity and observant compassion in vibrating brush strokes and juxtaposition of pulsating colours.

\section{Biographical notes.}

Lucian Grigorescu was born on February 1, 1894 in Medgidia [1], a city in Dobrogea, almost equidistant from both the Black sea and the Danube River situated at $24 \mathrm{~km}$. from the famous site of Cernavoda whose history extends thousands of years back to the Neolithic period [2]. His love of nature was revealed during his early high school studies at Constanta and Braila, where he often took long walks through the marshes. He continued his studies at the Academy of Belle Artes in Bucharest, respectfully remembering his teacher Gabriel Popescu as a 'highly modest man' [3]. Unfortunately these years were interrupted by military training and fighting on the front during WWI in 1916, an experience which left him wounded, returning in 'crutches and overwhelmed' [4]. After earning his diploma in Bucharest in 1920, he opened a personal exhibit which was followed by three years in Rome, of which he later confessed that 'the blue intensity of the sky devoid of transparency exhausted him' and thus he went to Paris, where he enrolled in the private Academy La Grande Chaumiere and Academy Ranson to study with Bissiere and Lapicque [5], but endured misery and 
hunger supporting himself with odd jobs. Finally, with money earned from costume designs for various theater productions, he managed to travel to Cassis-sur-Mer, where he established himself for the next 12 years, having discovered the fascination with the sunlit landscape of the south of France similar to Matisse, Picasso and Derain [6]. During this time however, Lucian Grigorescu continued to remain active in the artistic life of Romania by participating in Official Exhibitions and group exhibits such as the Artistic Youth, Our Group (which later became the New Group in 1939), and the Arts [7]. He also exhibited in Europe at the Hague, Venice, Bratislava, Prague, Helsinki, Dresden and in 1937 he became an Associate member of the "Artistic Youth" [8].

From the travels through Rome and France, Lucian Grigorescu discovered the atmospheric vibrations through which light dematerializes volumes, and while he adopted the ephemeral look of Impressionism, and continued the sensibility of his famous predecessor whom he admired, Nicolae Grigorescu, he infused his works with the new international approach to the depiction of form [9]. At first he felt spiritually attached to Ion Andreescu whose works indicate a lyrical sensitivity to tonalities which suggest forms and their spatial relationships. During his sojourn in the South of France, Lucian Grigorescu discovered the 'joy of painting' through the opulent effect stemming from the application of paint in thin layers of refined and harmonious colors [10]. Although his painting remains dedicated to 'plain-air', his work is Post-Impressionist echoing the geometrical order of the construction of forms of Paul Cezanne which transformed the visible reality of landscape through the strong sensibility of the painter. The years in Cassis were punctuated often by difficult misery, but in 1940 Lucian Grigorescu organized a personal exhibit at the Athenaeum in Bucharest [11]. Upon his return to
Romania, the painter continued the pictorial lyricism and joy of color aiming toward an ideal synthesis of color, light and form, representing reality filtered through an intensely subjective experience and gaining the label of 'the most painterly painter' [12]. Lucian Grigorescu returned to Romania at the outbreak of WWII working mainly in Dobrogea, whose light he considered "pearly and miraculous" [13] and in Bucharest where he was one of the few painters to render vedute of the city during the war years in oil, gouache and watercolor. He died on October 28, 1965 in Bucharest.

\section{Artistic philosophy and style.}

Lucian Grigorescu was an highly original painter whose oeuvre harmoniously fuses impressionistic techniques with an abstract expressionism, based on the deliberate and rationally articulated construction of forms and chromatic virtuosity. He strongly believed that artistic creation requires conscientious and considerable effort and energy, founded on complex personal discoveries and sensible experiences [14]. While Lucian Grigorescu appropriated the rational and geometric lessons of Cezanne and the colorism of the fauves, his lyrical and ardent temperament led him to an emphasis on chromatic verve and atmospheric luminosity [15]. It is important to note that while various influences can be detected in the work of this great colorist, he never copied any particular style, claiming that influences are necessary without blindly and slavishly following them' [16] as they must be felt in order to be authentic and the essential element remains continuous and diligent work. His palette reveals an affinity for the emerald greens, cadmium reds, ocher and intense blues applied in a symphony of vibrant color that assured the architectural composition of the work [17]. The infusion of light dematerializes volumes accentuating the spontaneity of the paint application and thereby reinforcing the 
sheer joy of nature and of the act of creation [18].

\section{The oeuvre.}

Early in his career, Lucian Grigorescu's works revealed affinities to the impressionist style, but in the 1920's his works began to show the influence of Derain and Cezanne while his discovery of Cassis led to a brighter and richer palette as his painting "became characterized by a robust spontaneous sensuality and an unbridled vitality in its evocation of nature" [19]. Working backwards from the constructivist abstraction the artist arrives at a personal combination of fidelity for the concrete reality, expressed analytically through a synthesis of forms spontaneously rendered in a chromatic play of loosely applied paint [20].

"Landscape with a Red Church" (Figure 1) exemplifies the planar construction of shapes juxtaposed in layers of vivid red balanced by a cold green and a clear blue with ochre-brown tones. The high horizon line situates the viewer in an elevated almost birds eye view of the church whose brightness focuses the attention but whose sketchy rendering with bold and rapid brushstrokes, characteristic in the art of Grigorescu, implies a spontaneity and immediacy of vision, hiding the deliberate construction of the picture plane. This work was originally part of the collection of Gabaret Avachian and was sold at the Spring Auction of Artmark in 2011 for 10000 euros [21].

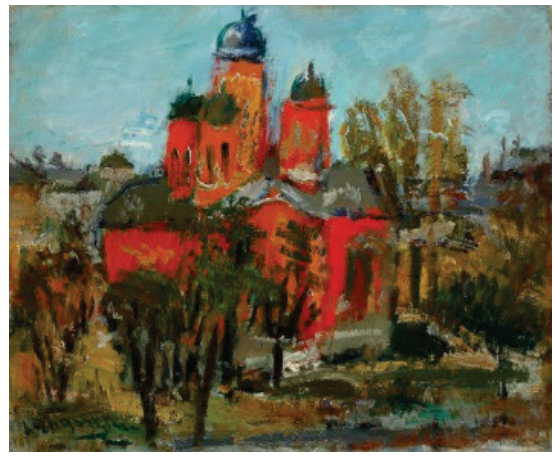

Figure 1. Landscape with Red Church
The synthetic constructivism of Cezanne is apparent in "Dobrogean Street" (Figure 2.), a work that indicates the starting point in the work of Lucian Grigorescu toward a personal impressionistic vision framed within a generalized postimpressionism. The restricted palette of earth tones renders a concrete verism to the scene according to classical even architectural principles while the quickly sketched figures focus the perspective and provide a counterpoint to the modular construction of the planes [22, 23]. The uniform application of paint reinforces the linear rhythm of the architectonic construction, but the diagonally placed parallel brush strokes give the impression of hastiness in their rendering, contradicting the carefully constructed composition. The diagonal line of the road centers the attention of the viewer on the middle ground and the distant figure placed almost in the center of the composition balancing the geometrical shapes of the houses. This painting was sold at the Oriental auction at Artmark in 2010 for 30000 euros and included a label of participation in the exhibit 'Artistic Values' from Bucharest collections, MNAR, Muzeul Colecțiilor de Artă, București, 2002 [24].

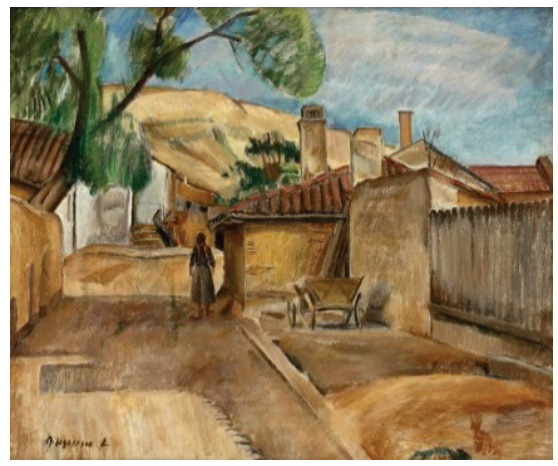

Figure 2. Dobrogean street

Among the relatively few portraits Lucian Grigorescu painted, the "Harlequin" (Figure 3.) should be noted for the stark contrast between the nostalgic sadness of the figure and the bright colors of her clothing. The classical three quarter turn of the figure is 
thrust into the foreground by the intense amorphous shape of the chair, crowned by the anchoring curtain cleverly placed behind the figure, to balance the cerulean emptiness bringing the viewer back to the dreamy sadness of the lady. The golden hue of the costume highlights the bright blue which tonally complements the background further evidencing the figure. Yet the carefully constructed composition and the vivacious tonality leaves the viewer baffled about the inexplicable sadness or melancholy of the figure. The evanescent, dematerialized face suggests a Venetian setting of arabesques, carnival and lyricism [25]. This work can be seen in the collection of the K.H. Zambaccian Museum in Bucharest [26].

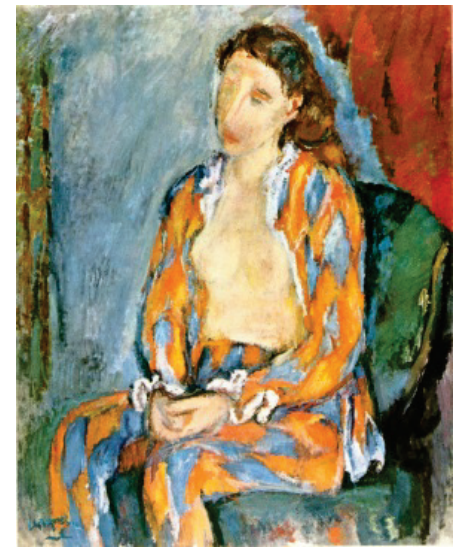

Figure 3. Harlequin

The twelve years Lucian Grigorescu resided in the south of France infused his works with the brilliant sunlit color that fascinated him as much as it did in previous decades numerous illustrious artists, and inspired him to create a series of paintings of Cassis. These early works of the 1920's reveal the gradual evolution of Grigorescu's unique style from the formal analysis and construction of shapes to the later exclusive reliance on color and paint, to frame the motif visible in the cycle of works depicting Balcic, another preferred location of the artist. These picturesque land and seascapes are often characterized by high horizon lines and sweeping panoramic vistas peppered with colorful highlights of cadmium roofs and contrasting details evoking an aura of serenity and peace. In Figure 4 the "View of Cassis" presents a dreamy composition in which the dabs of color appear like a mosaic, clearly separating the composition into two distinct registers. The distant ultramarine horizon of the sea imperceptibly merges into the hazy sky grounded with the centralized placement of the three flagpoles whose flags appear to be gently fluttering in the breeze. The sunlit façade of the foreground house vibrates in the sun further accentuating the misty view of the empty street suggesting a lazy afternoon siesta. This work was sold at the Artmark Impressionsism and Postimpressionism auction in 2011 for 19,000 euros [27].

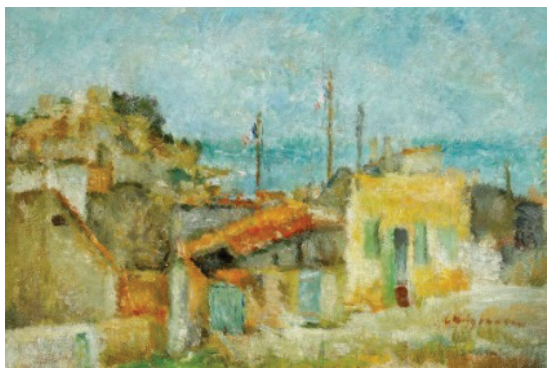

Figure 4. View of Cassis

During the 1940's Lucian Grigorescu is one of the few artists to paint numerous views of Old Bucharest thus preserving the views of the capital during the difficult years of WWII. The majority of these works in oil, gouache or watercolor present the same characteristic high horizon line, most likely having been painting from the studio, and a mosaic of rooftops quickly sketched in assertive and spontaneous strokes of rich complementary colors. In later decades, the painter focused his attention on still life carefully arranging various bowls of fruit, or flowers in his studio. These works are infused with the afternoon light creating a warm and inviting atmosphere dominated by red or orange tonalities, which are often contrasted and fragmented by complementary vermillion. 


\section{Conclusion.}

In conclusion, this brief survey of the work of Lucian Grigorescu, examined the unique modernist vision of the important Romanian postimpressionist painter who, while continuing the sensibility of his illustrious predecessor, the great painter Nicolae Grigorescu, discovered a distinctive balance between tradition and modernity. By incorporating expressionistic elements in the construction of forms bathed in light and rendered in a dense chromatic symphony, Lucian Grigorescu became an important Romanian colorist, characterized through his vivacity and chromatic combination of colors.

\section{References.}

1) Argintescu-Amza N., Lucian Grigorescu, Editura Meridiane, Bucuresti, 1969, p. 68 .

2) Ciornei Anisoara, Local History of Medgidia, retrieved from http://medgidiacity.ro/despre.php, February 14, 2013

3) Argintescu-Amza N., Lucian Grigorescu, Editura Meridiane, Bucuresti, 1969, p. 68 .

4) Argintescu-Amza N., Lucian Grigorescu, Editura Meridiane, Bucuresti, 1969, p. 69.

5) Argintescu-Amza N., Lucian Grigorescu, Editura Meridiane, Bucuresti, 1969, p. 69.

6) Muzeul National Brukenthal, Galeria de Arta Romaneasca (National Brukenthal Muzeum, Romanian Art Gallery), Iulia Mesea, Sibiu 2010, Editura Altip Alba-Iulia, p. 134-136.

7) Pavel Amelia, Pictura Romaneasca Interbelica - un capitol de Arta Europeana, Editura Meridiane, Bucuresti, 1996, p. 52.

8) Pavel Amelia, Pictura Romaneasca Interbelica - un capitol de Arta Europeana, Editura Meridiane, Bucuresti, 1996, p. 113.

9) Muzeul National Brukenthal, Galeria de Arta Romaneasca (National Brukenthal Muzeum, Romanian Art Gallery), Iulia Mesea, Sibiu 2010, Editura Altip Alba-Iulia, p. 134-136.

10) Argintescu-Amza N., Lucian Grigorescu, Editura Meridiane, Bucuresti, 1969, p. 69-70.
11) Argintescu-Amza N., Lucian Grigorescu, Editura Meridiane, Bucuresti, 1969, p. 69-70.

12) Muzeul National Brukenthal, Galeria de Arta Romaneasca (National Brukenthal Muzeum, Romanian Art Gallery), Iulia Mesea, Sibiu 2010, Editura Altip Alba-Iulia, p. 134-136.

13) Argintescu-Amza N., Lucian Grigorescu, Editura Meridiane, Bucuresti, 1969, p. 70 .

14) Argintescu-Amza N., Lucian Grigorescu, Editura Meridiane, Bucuresti, 1969, p. 73 .

15) Florea Vasile, Romanian Art, Modern and Contemporary ages, Meridiane Publishing House, Bucharest, 1982, p. $178-179$.

16) Argintescu-Amza N., Lucian Grigorescu, Editura Meridiane, Bucuresti, 1969, p. 70 .

17) Muzeul National Brukenthal, Galeria de Arta Romaneasca (National Brukenthal Muzeum, Romanian Art Gallery), Iulia Mesea, Sibiu 2010, Editura Altip Alba-Iulia, p. 134-136.

18) Dragoi Livia, Muzeul National de Arta, Cluj, Galeria Nationala, Idea Print Cluj, 1997, p. 72.

19) Vlasiu Ioana, The Dictionary of Art, volume 13, ed. Jane Turner, Grove Oxford University Press, Macmillian Publishers Limited, 1996, p. 650-651.

20) Carneci Magda, Lucian Grigorescu, Ed. Meridiane, 1989.

21) Landscape with Red Church, sold at auction at http://www.artmark.ro/luciangrigorescu-peisaj-cu-biserica-ro-ie.html

22) Oprea Petre, Lucian Grigorescu, Muzeul de Arta al RSR, Bucuresti, 1967.

23) Retrospectiva Lucian Grigorescu, MNAR Muzeul Colectiilor, Bucuresti 1994.

24) Dobrogean Street, sold at auction at ArtMark http://www.artmark.ro/luciangrigorescu-uli-a-dobrogeana.html

25) Argintescu-Amza N., Lucian Grigorescu, Editura Meridiane, Bucuresti, 1969, p. 28.

26) K.H. Zambaccian Muzeum http://www.mnar.arts.ro/Muzeul-KH-

Zambaccian

27) Cassis Landscape sold at auction at Artmark http://www.artmark.ro/luciangrigorescu-peisaj-la-cas 